引用文献

1）浜名克己：家畜診療，230，13～24 (1982).

2）浜名克己：主要症状を基礎にした牛の臨床，其田 三夫編，第 2 版，663～669，デーリーマン社，札 幌 (1982).

3) 望月 宏, 橋本善之: 先天異常, 21, 25 52 (1981).
4) 大森常良: 牛病学, 大森常良, 安藤敬太郎, 石谷 類造ほか編，263～269，309～319，355～361，近 代出版, 東京 (1981).

5) Patten, B. M.: Foundations of Embryology, 2nd ed., 457 462, McGraw-Hill Book Co., Inc. New York, San Francisco, London, Tronto. Kogakusha Co., Ltd. Tokyo (1964).

6) Thomson, R. G.: Rath. Vet., 3, 89 109 (1966).

\title{
技 術講座
}

\section{小動物臨床に拈けるクスリの使い方 (XXV) \\ 8. 抗炎 症 薬の薬理（その 2)}

柴田浩*

\section{2. 抗 炎症薬各 論}

すでに述べたように，抗炎症薬は炎症の過程のいずれ かのポイントを抑制し，治療へ導くことを目的とする.

したがって, 抗炎症薬の治療は一種の対症療法であるこ とを忘れてはならない。

現在用いられている抗炎症薬は，大体，表 4 のよらに 分類できる. 抗炎症薬は, 狭義では, 大部分の炎症に多 かれ少なかれ有效である非特異的抗炎症薬をいい，ステ ロイド系抗炎症薬，非ステロイド系抗炎症薬および抗炎 症性酵素薬がこれにあてはまるが，広義では，抗リウマ チ薬，抗痛風薬，膠原病などに用いられる免疫抑制薬な ぞの特殊な炎症に有効である特異的抗炎症薬も含める.

表 4 抗炎症薬の分類と代表薬

\begin{tabular}{ccccc}
\hline \hline 薬 物 & 群 & 代 & 表 & 薬 \\
\hline
\end{tabular}

ステロイド系抗炎症薬
非ステロイド系抗炎症薬

酸性

$\left\{\begin{array}{l}\text { サリチル酸系 } \\ \text { ピラゾリジン系 } \\ \text { アントラニル酸系 } \\ \text { インドール酢酸系 } \\ \text { プロピオン酸系 } \\ \text { フェニル酢酸系 } \\ \text { ベンゾサイアジン系 }\end{array}\right.$

塩 基 性

抗炎症性酵素薬

特異的抗リウマチ薬

特異的抗痛風薬

その他

アスピリン：ジフルニサル

フェニルブタゾン

メフェナム酸, フルフェナム酸

インドメタシン

イブプロフェン

ジクロフェナック

ピロキシカム

塩酸ベンジダミン

キモトリプシン, ブロメライン

金製剤, Dーペニシラミン

コルヒチン，アロプリノール

免疫抑制剂, 抗ヒスタミン薬など

* 山口大学農学部（山口市吉田1677-1）

1）ステロイド系抗炎症薬（steroidal anti-inflammatory drugs: SAID)

副腎皮質ステロイドは，本来，ホルモンであり，体内 では生理的に糖・蛋白・脂質・水・電解質などの代謝に 関係しているが，糖質コルチコイドは大量投与すると薬 表 5 ステロイド系抗炎症薬の主要薬物

\begin{tabular}{|c|c|}
\hline 一 般 名 & 商 \\
\hline コルチゾン & コートン, シェロソン, アドレソン \\
\hline ヒドロコルチゾン & $\begin{array}{l}\text { ハイドロコートソ, コートリル, コ } \\
\text { ーテフ, シェロソンF, ハイドロ } \\
\text { ドレソン }\end{array}$ \\
\hline プレドニゾロン & $\begin{array}{l}\text { コーデルコートン, プレドニン, プ } \\
\text { レゾロソ, ドニゾロソ, デルタュー } \\
\text { ト, シェリゾロン }\end{array}$ \\
\hline トリアムシノロン & ケナコルト, レダコート \\
\hline デキサメタゾン & $\begin{array}{l}\text { ユルソン, オルガドロン, メタゾロ } \\
\text { ソ, デクタン, カルロン }\end{array}$ \\
\hline ベタメタゾン & $\begin{array}{l}\text { リンデロン, ベトネラン, ベトネゾ } \\
\text { ール }\end{array}$ \\
\hline パラメタゾン & パラメゾン，ハルドロン \\
\hline
\end{tabular}

表 6 全身的に投与されたステロイド系抗炎症薬の 効力比

\begin{tabular}{lccc}
\hline \hline ステロイド名 & 合成年 & $\begin{array}{c}\text { 抗炎症 } \\
\text { 作 }\end{array}$ & $\begin{array}{c}\text { 塩類貯 } \\
\text { 作用 }\end{array}$ \\
\hline コルチゾン & 1946 & 0.8 & 0.8 \\
ヒドロコルチゾン & 1951 & 1.0 & 1.0 \\
プレドニゾロン & 1955 & 4.0 & 0.8 \\
メチルプレドニゾロン & 1956 & 5.0 & 0 \\
トリフムシノロソ & 1956 & 5.0 & 0 \\
デキサメタゾン & 1958 & 30 & 0 \\
ベタメタゾン & 1958 & 25 & 0 \\
パラメタゾン & 1960 & 10 & 0 \\
\hline
\end{tabular}

注）数值はヒドロコルチゾンを 1.0 としたときの割合 
理作用として強い抗炎症作用を示す．抗炎症作用の強さ は糖質作用の強さと比例するが, 塩類作用が副作用とし て強く現われる. そこで, 抗炎症作用が強く, しかも副 作用の弱い種々の誘導体が合成されたが（合成副腎皮質 ホルモン), これらがステロイド系抗炎症楽 (SAID) と 総称される. その主なるのを表 $5 に$ に また, その特長を 表 6 亿示す. 合成副腎皮質ホルモンは後期に作られたも のほど塩類作用は弱く, 抗炎症作用が強くなっている. なお，表 6 に示した数値は検定法により多少異なってく るので, 1 つの目安と考觉るのがよい.

〔作 用 機 序〕

SAID の抗炎症作用の機序として主張されているもの のらち, 主なものをあげる.

(1) PGs 産生抑制作用：リン脂質からアラキドン酸 に変化させるホスホリパーゼ $\mathrm{A}_{2}$ を間接的に阻害する. すなわち, SAID は細胞に入って特異的な蛋白（マクロ コルチン,リポモデュリン）を合成し，これらがホスホ リパーゼ $\mathrm{A}_{2}$ 活性を抑制すると考光られている. SAIDは 次に述べる非ステロイド系抗炎症薬と異なり, シクロオ キシゲナーゼ系ばかりでなく、リポキシゲナーゼ系も抑 制するので，その作用は強力となる (図 2 参照).

(2) 白血球の遊走および機能の抑制 : 白血球の炎症局 所への遊走を抑制することにより，白血球に由来するラ イソソームの炎症性化学因子による過剩な作用を抑兄 る. 白血球遊走の抑制は, 白血球遊走作用を有する $\mathrm{PGs}$ の合成阻害に基づく間接的作用か，あるいは直接的作用 も加えた両方の作用によると思われる.

(3) ライソソームからの水解酵素遊離の抑制 : ライソ

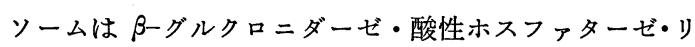
ゾチームなどの水解酵素を含んで括り, これらが炎症性 化学因子となるが, SAID はライソソーム膜を安定化し て，これらの酵素の遊離を抑制する。

(4) 細胞膜あるいは原形質膜の保全 : 細胞膜や原形質 膜に作用して, 水の細胞内貯留拉よび細胞の腫脹や破壊 を防ぎ，抗炎症作用を示す。

(5) 蛋白合成阻害作用 : 蛋白合成阻害作用により, 線 維芽細胞の増殖やコラーゲンの発育を抑制する.

〔副作 用〕

SAID は效果が顕著である反面, 副作用も多彩であ り，ときには生命の危険をともなう場合がある. 人医臨 床では, 感染症の誘発, 消化性潰瘍, 副腎不全, 骨多孔 症などの重症副作用 (major side-effect) と円形顔貌 (ム ーンフェイス), 浮腫, 痤瘡などの軽症副作用 (minor side-effect）に分け，治療に際して十分に配慮している.

〔臨 床応用〕

獣医臨床では, SAID は抗炎症薬として比較的よく利 用されている. 内科領域ではケトン症, 乳熱, 妊娠中毒, 蹄葉炎などに全身投与される. 外科領域では関節炎, 腱
鞘炎, 筋炎, 外耳炎などに全身および局所に適用される. 皮膚科領域（アレルギー性皮膚炎，湿疹，滲出性皮膚炎 など)拉よび眼科領域では主として局所的に応用される. その他, ショックの治療あるいは防止のために輸液に混 合したり, 直接静脈内注射して用いられる.なお, 副作 用としては感染症の悪化と誘発感染症が最も危険である ので注意を要する。また, 創傷, 骨折, 骨栄養障害およ び鬱血性心不全に対しては禁忌である.

2）非ステロイド系抗炎症薬（non-steroidal antiinflammatory drugs: NSAID)

近代医学に㨟ける抗炎症薬の始まりは 19 世紀末のア スピリンの開発であったが, SAID が現われ，一時はこ れが万能であると考觉られていたので NSAID の開発は 下火となっていた. しかし, その後, SAID の功罪が明ら かになるにともない NSAID が見直され，再び NSAID の開発が盛んになり，現在にいたっている.

現在使用されている主な NSAIDを表 7 亿示す。 大部 分は酸性を呈する酸性 NSAID であるが，一部塩基性の ものがある. NSAID は, 酸性条件のほうが, 白血球の 食作用や抗菌作用を抑制しやすく，また，細胞内の NSAID 濃度が高くなる. したがって, 塩基性 NSAID は酸性 NSAID にくらべ抗炎症作用は弱く（鎮痛作用は 強い)，それだけ胃障害をはじめとする副作用も弱いの で，主として急性の軽い炎症に用いられている.なお， NSAID は程度の差はあるものの, いずれも鎮痛作用と 下熱作用をあわせもつ.

[作 用 機 序]

NSAID の抗炎症作用の機序として現在提唱されてい るもののらち，主なるのをあげる.

(1) PGs 生合成抑制作用: NSAID は作用の強弱はあ るものの, いずれもシクロオキシゲナーゼを阻害し, PGs の生成を抑制する (図 2 参照).

(2) 酸化的リン酸化の抑制 : ミトコンドリアの酸化的 リン酸化を脱共役して, 炎症における発熱, 白血球遊走, $\mathrm{CM}$ の放出, 線維芽細胞の増殖などに必要な ATP の産 生機構を抑制する.

(3) 白血球の遊走および食作用の抑制：SAID と同様 である.

(4) ライソソームからの水解酵素遊離の抑制： SAID と同様であるが，すべての NSAID がこの作用を有して いるわけではない、また, ライソソームから遊離した酵 素の作用も抑制すると考光られている.

(5) フリーラジカルの捕促作用 : $\left(\cdot \mathrm{O}_{2}^{-}\right)$や $\left(\cdot \mathrm{OH}^{-}\right)$ のフリーラジカルは活性に富み, アラキドン酸からの PGs の合成, 白血球の遊走を促進する過酸化脂質の生成, ライソソーム膜破壊などの作用を有している. NSAID はこれらのラジカルを捕促することにより抗炎症作用を 発現する. 
技術講座

表 7 非ステロイド系抗炎症薬の分類と主要薬物

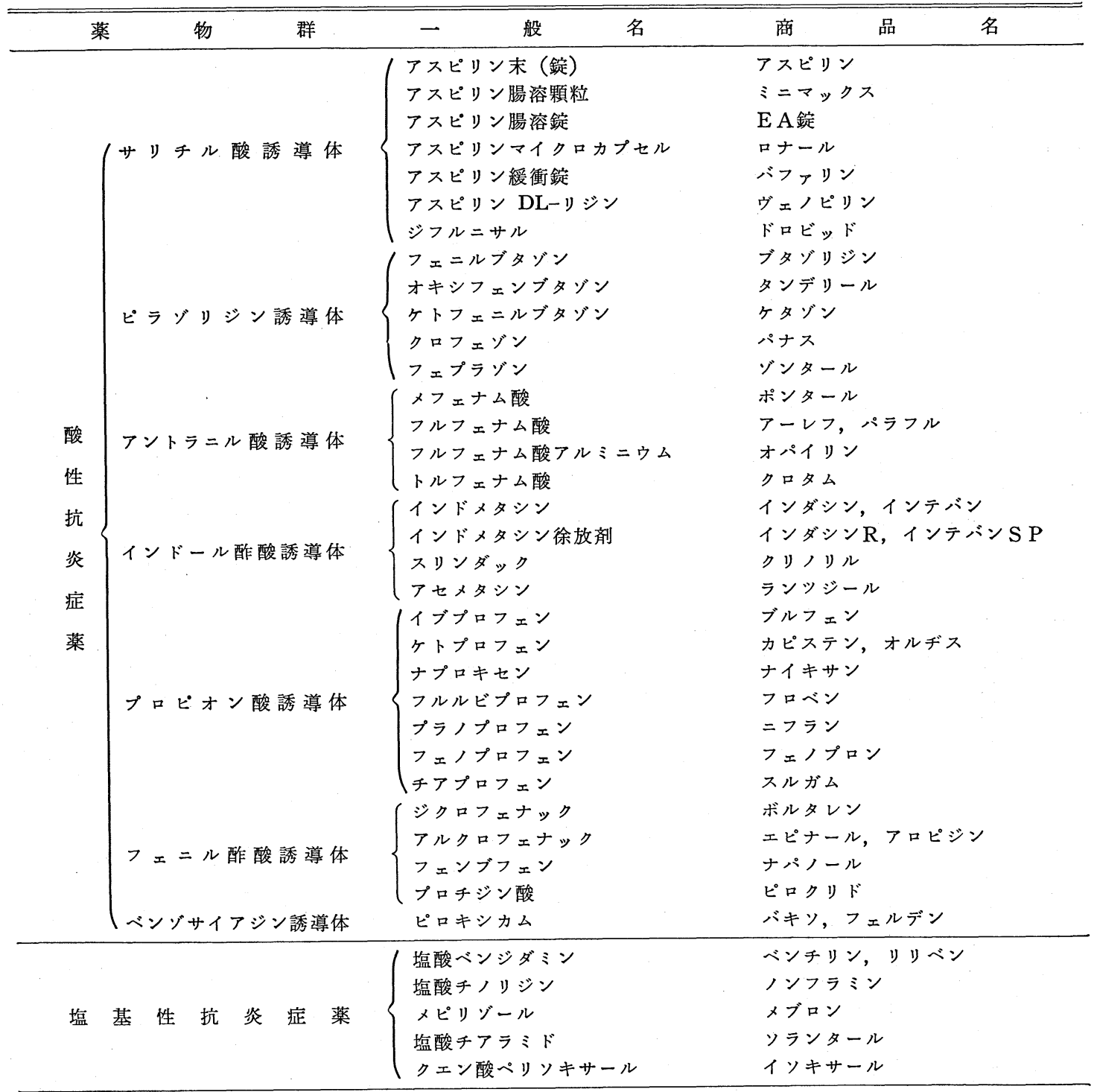

(6) 中枢神経系に対する作用：炎症作用は局所だけで なく中枢神経系も関与していると考えられており，中枢 作用（鎮痛作用）を有するNSAID は局所作用とともに 中枢を介して抗炎症作用が発現される.

(7) 内因性抗炎症ペプチドの遊離作用：血清蛋白に結 合している抗炎症ぺプチドがあり，これを遊離させて抗 炎症作用を発揮するという考党だが，この考えは現在否 定されている.

\section{〔副作 用〕}

NSAID の共通的副作用は胃障害である. 胃壁におい て胃液分泌低下，血管拡張，胃緊張低下の作用を示し， 胃の機能を正常に維持しているのが PGs であるが,
NSAID はこの PGs の合成を阻害するので胃障害を呈す るのは当然である. この点は SAID も同様であるが, NSAID はSAID と異なりもっぱら全身的に適用される ので問題となる.その他の副作用として, 腎障害, 肝障 害, 血液障害などがある.これらの副作用の程度は薬物 により異なる.

\section{〔副作 用 軽 減のエ夫〕}

NSAID はしばしば胃障害の副作用をともならので, 胃障害を少なくするためにさまざまの努力がなされてき た.

(1) 用型の工夫 : アスピリンの腸溶錠, 腸溶顆粒, マ イクロカプセル化, 緩衝作用をもたせたもの, インドメ 
技術講座

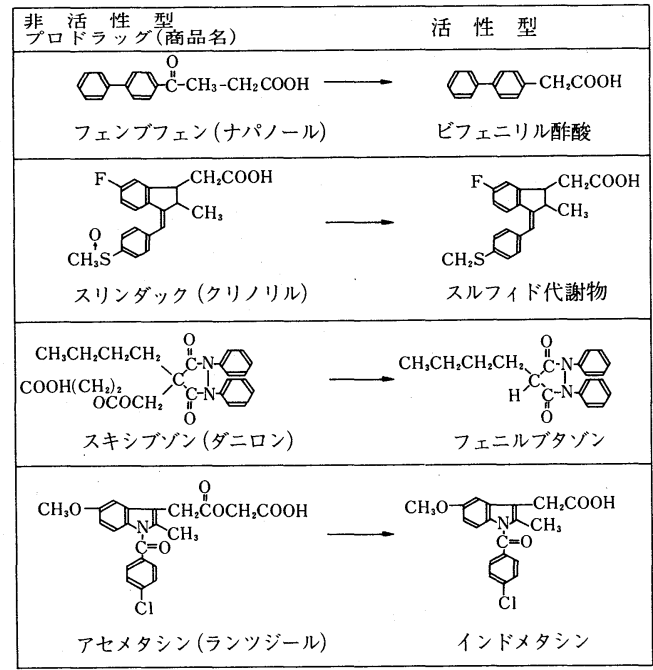

図 3 非ステロイド系抗炎症薬のプロドラッグ

タシンの徐放セプセルなどがある(表 7 参照).これらは 副作用の軽減とともに作用の持続化も目的としている. このように製剤上の工夫により目的にかなった時間, 部位，用量を得ることをドラッグデリバリーシステム (drug delivery system) という.

(2) プロドラッグ (prodrug) : 一般に，プロドラッグ とは薬物の化学構造を投与するときは非活性型とし, 体 内（主に肝）で代謝されてはじめて活性型に変化して効 力を発揮するものをいらが，NSAID に拈けるプロドラ ッグ化の最大の目的は胃障害を避けることにある(図 3 ).

(3) 投与経路の工夫 : 胃を経ない投与経路の一つとし て坐薬が考えられるが，NSAID に和いては全部肛門坐 薬である。これには肝に括ける代謝が少ないという利点 あある. 肛門坐薬は, インドメタシン, ジクロフェナッ クなどで用いられている.このほか経皮的に吸収させる 方法, すなわち, 外用液や貼布剂がインドメタシンなど で試みられている.

以上のように，副作用が少なく効果が持続する新しい NSAID が次々に開発されたことにより，最近，人医臨 床では NSAID の応用が飛躍的に伸びている.
表 8 非ステロイド系抗炎症薬の人医臨床における 主な適応 (塩川 ${ }^{10)}$ より改変)

膠原病，リウマ 慢性関節リウマチ, リウマチ熱, 変形 千, 自己免疫病 性関節症, 変形性脊椎症, 腰痛症, 春 椎分離症, 頸肩腕症候群, 関節 (周囲) 炎・関節痛腱鞘炎・腱周囲炎, 症候性 神経痛, 痛風発作, 紅斑症, 結合織炎, 捻挫痛, 打撲症, 筋肉痛

外科領域外傷・手術

感染 症感冒, 咽 - 喉頭炎, 扁桃炎, 急 - 慢性 気管支炎, 急性中耳炎, 副鼻腔炎, 骨 盤内炎症, 膀脂炎, 前立腺炎, 副睪丸炎

歯科・ 口腔外科抜歯後痛(歯痛)，歯槽骨膜炎，歯根膜 領域

眼 科 領 域 炎・歯䯣炎

皮膚科領域

前眼部炎症, 強膜炎, 麦粒尰

湿疹，アトピー性皮膚炎，掌蹠膿疮症， 带状疮疹

婦人科領域会陰裂傷, 軟産道損傷, 分婏後痛 - 後 陣痛, 月経困難症・月経痛

\section{〔臨 床 応 用】}

獣医臨床では，NSAID は胃腸管障害や腎障害などの 強い副作用があるといらことで, 犬や馬の跛行の鎮痛消 炎薬，犬や猫の抗リウマチ薬などにわずかの利用がある が，ほとんぞ用いられていなのが現況である.しかし， 前述したように NSAID の最近の進歩はめざましく，副 作用の少ない新しい NSAID が次々に開発されているの で, 獣医臨床でもこの新しいNSAID の応用を考劣るべ きであるう．参考のために人医臨床における NSAID の 適応を示して扩く（表 8).

\section{3）抗炎症性醳素薬}

生体内にある酵素, とくに蛋白分解酵素が抗炎症薬と して用いられている. 臨床面では「消炎酵素剂」と呼ば れる. 現在使用されている主な酵素製剤を表 9 亿示す. この系統の薬は, 注射, 経口, 局所適用などにより投与 されるが，全身的に投与された場合の体内動態・薬効な どは不明な点が多く，本剤による療法に対する理論的な 裏付けは乏しい。

\section{〔作 用 機 序}

壊死組織や变性蛋白などの炎症の産物を分解すること により，炎症の治癒や組織の修復に作用すると考兄られ ている. その他，CMの放出作用もあるといら報告もあ

表 9 抗炎症性酵素薬 $\left(\right.$ 橋本 $^{2)}$ より改変)

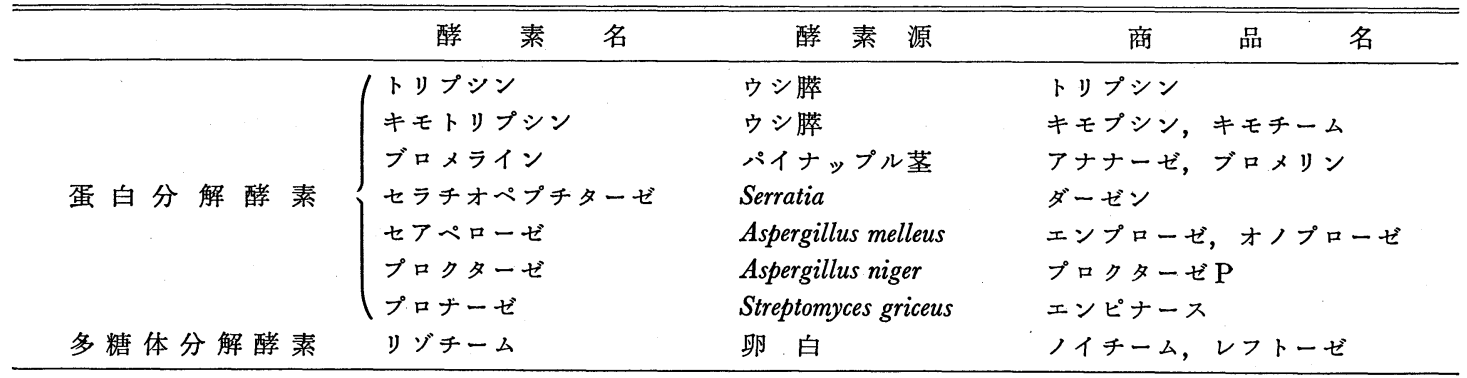


るが，明らかではない。

\section{〔副 作 用〕}

抗炎症作用は NSAID にくらべてはるかに弱いが，そ れだけに副作用は注とんどないと考兄られている．ただ し，注射ではアレルギーが起こることがある.

\section{〔臨 床 応 用〕}

獣医臨床では SAID に次いで比較的用いられている. ブロメラインは打撲, 捻挫, 骨折, その他の外傷による炎 症, フレグモーネ, 関節炎などに経口的に投与される. ただし, 消化管の潰瘍, 重篤な肝・腎障害, 血液凝固不 全には使用してはならない.トリプシンは化膿創, 化膿 性皮膚疾患, 火傷などの壊死組織の融解除去および肉芽 形成促進のために，主として局所的に使用される. キモ トリプシンは皮下注射により各種炎症疾患に用いられ る.

\section{4) その他の抗炎症薬}

金製剂, D-ペニシラミンは抗炎症作用や鎮痛作用が弱 く, 慢性関節リウマチ以外の関節炎にはほとんど効果が ないので, 特異的抗リウマチ薬 (specific antirheumatic drugs）と呼ばれている（表 10）。括もな作用機序として は，金製剤は単球に貪食されて単球の貪食機能を低下す ること，D-ペニシラミンはその $\mathrm{SH}$ 基がリウマトイド 因子の SS 結合を解離してリウマトイド因子を分解する ことが主張されているが，両者ともまだ明らかにされて いない，獣医臨床に执いてもリウマチ性炎症への利用が ある.

クロロキンはもともと抗マラリア薬であるが，抗りウ マチ薬としても用いられた。なお，本剤はわが国では眼 障害をはじめとする副作用のために使用されていない が，世界的にはまだ使われている，中性プロテアーゼお よびュラゲナーゼの阻害により関節軟骨の破壊を防止す ること, ライソソーム膜を安定化すること, 炎症細胞に 対しては多形好中球の走化性と貪食を抑制し, 線維芽細 胞の発育, 結合組織の発達を抑制することなどが作用機 序と考えられている.

特異的抗痛風薬（痛風治療薬）としてコルヒチン， ア ロプリノール，プロベネシドなどがある.コルヒチンは

表10 特異的抗リウマチ薬および抗痛風薬

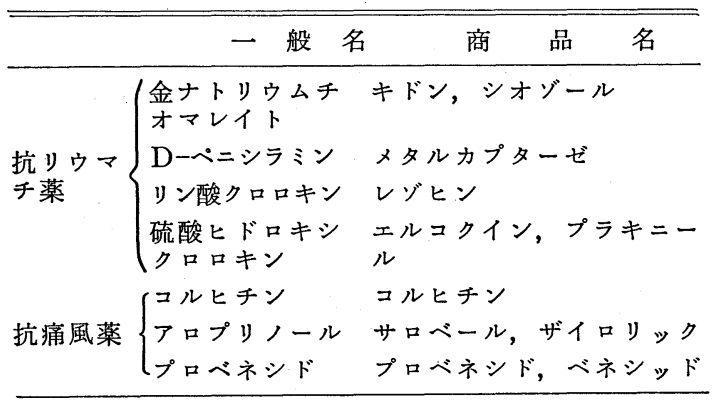

微小管抑制薬 (microtubular inhibitors) と呼ばれるが, 作用機序としては，好中球，マクロファージの細胞質内 でチュブリンと結合して微小管の形成を阻害し，その結 果, 細胞分裂を防止すること, 領食や遊走を妨げること, ライソソーム酵素や CM の放出を妨げることが考兄ら れている.アロプリノールは尿酸生成の抑制作用, プロ ベネシドは尿細管に拈ける尿酸排泄の促進作用を有して いる.

その他, 1960 年代半ばに用いられたものにジメチル スルホキシド (dimethyl sulfoxide: DMSO) がある.こ れは生体内にも存在する有機化合物であるが, 有機溶媒 として広く使用されているるのである. 鎮痛作用, 抗炎 症作用などを有し，局所の皮膚に塗布することにより， とくに慢性関節リウマチに有効であるとさていたが，眼 障害をはじめとする副作用が問題とされ研究は中止され た. しかし, 最近, 本剤が見直され, 研究が再び開始さ れたようである. 獣医臨床では競走用の馬および犬の筋 骨格外傷において腫脹を減じるために用いられた。

以上，抗炎症薬に関して，その概略を紹介した。炎症 そのものが生体反応の過程であり, 多くの生化学反応が 集積したものである. その生化学的機序に関する研究は まだ端緒についたばかりであり, したがって, 抗炎症薬 の生化学的機序もまだ明らかになっていない。しかし, 現在, 炎症研究は精力的になされており, 今後, 炎症の 機序が明らかにされるにつれ, 炎症反応に対する特異的 な抗炎症薬が開発され，炎症療法に新しい時代がくるも のと思われる。

\section{参考文献}

1）藤原元始, 柴田章次: 薬理学基礎実験法, 第 1 版, 79 84, 杏林書院, 東京 (1982).

2) 橋本裕一, 伊藤文雄, 伊野忠雄, ほか: 臨床薬理 学, 第 1 版, 370 406, 朝倉書店, 東京 (1979).

3) 吐山豊秋: 家畜薬理学, 第 1 版, 138 162, 養賢 堂, 東京 (1985).

4) 本間光夫 : からだの科学, 114, 77 92 (1983).

5) Jones, L. M., Booth, N. H., McDonald, L. E.: Veterinary Pharmacology and Therapeutics, 4th ed., 659 679, 821 826, Iowa State Univ. Press, Iowa (1978).

6) 栗山欣弥, 北川晴雄: 生化学的観点からみた薬理 学, 第 1 版, 167 188, 315 324, 410 423, 理 工学社, 東京 (1981).

7) 黒沢亮助, 酒井 保: 家畜外科診療, 第 2 版, 443 ～446, 養賢堂, 東京 (1984).

8) 小野 豊: 家畜病理学総論, 第 1 版, $99 \sim 111$, 朝倉書店, 東京 (1982).

9) Ruckebusch, Y., Toutain, P.-L., Koritz, G. D.: Veterinary Pharmacology and Toxicology, 321 331, MTP Press Limited, Lancaster (1983). 
資

10) 塩川優一：炎症と抗炎症薬の実際, 第 1 版, 49 84, 113 140, 162 178, ライフ・サイェンス, 東京 (1983).

11）柳浦才三 : 図説 薬理学, 第 2 版, $52 \sim 60$, 朝倉
料

書店, 東京 (1977).

12) Yoxall, A. T., Hird, J. F. R.: Pharmacological Basis of Small Animall Medicine, 85 137, Blackwell Scientific Publications, London (1979).
1977 年以降, 農林水産省家畜衛生試験場 で 家畜衛生 研修会（病性鑑定病理部門）が開かれ，1984 年までの間 に 251 件の事例が検討されてきた. その数は今後毎年増 加していく，過去にどのような事例報告がされたかを調 ベることは病変の解析上大事であるが，それには大変な 労力と時間が必要である. しかし，コンピュータを使用 すれば，非常に短時間で検索可能である. そこで NEC 9801-F を用いて, 年度別に事例番号, 提出者, 提出県, 動物名，診断名を入力し，それを用いて検索できるよう にファイルを作るプログラムを作成した，症例としては 本会誌に記載されているすのを用いた.

プログラムはフローチャト 1 に示したように，データ の入力(追加), 検索, 修正, 終了の 4 つのサブルーチン で構成されている. プログラムを RUNすると，〔1一追 加, 2一検索, 3一修正, 4一終了〕之問うてくるので, 目的の番号を入力する.

\section{1. 入 力}

1一入力（追加）では，19** 年と入力すれば KEN-** といら名のファイルができる. 事例番号, 提出者, 提出 県, 動物, 診断名の順で入力する. 1 つのデータの入力 が終わると，また事例番号を聞いてくるので，データが ある場合には続けて入力する. 終わりあるいは途中で中 断する場合には“0”を入力すると, 最初の〔1一追加, 2一検索, 3一修正, 4一終了丁に戻る.

\section{2. 検索（フローチャート2）}

2一検索では,〔1一事例番号, 2一提出者, 3一県, 4動物，5一診断名】と検索したい項目を聞いてくるので, 検索したい項目の番号を入力する. 次いで，検索したい 言葉 (KEYWORD) を聞いてくるので入力する.ささら に〔検索したい最初の年は〕と聞いてくるので，19**と 入力し，引き続き〔検索したい最後の年は〕と聞いてく るので 19** と入力する.〔1-CRT, 2-PRINTER〕と出

* 農林水産省家畜衛生試験場九州支場（鹿児島柬中山 町2702)
力先を画面かプリンターかと聞いてくるので 1 かを 2 を 力する. あとは, コンピュータが検索してくれる. 検査 項目が “動物”で, “馬”を検索語として検索した結果を 検索例 1 に示している. KEN=1977 は 1977 年を意味 し，その下はその年次の事例番号を意味している.また， 事例番号から診断名までをあわせて検索したい時は, 790

$$
\text { 『フローチャート1』 }
$$

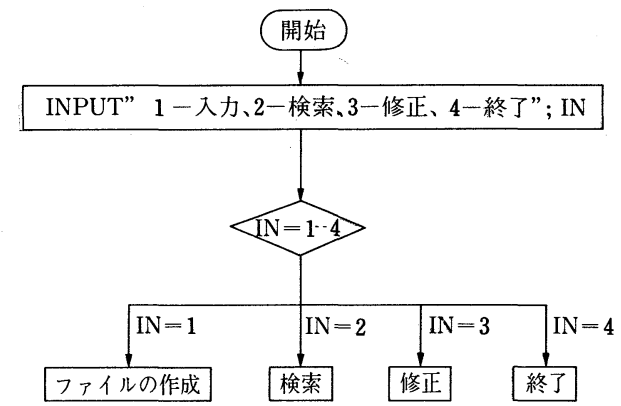

『フローチャート2】

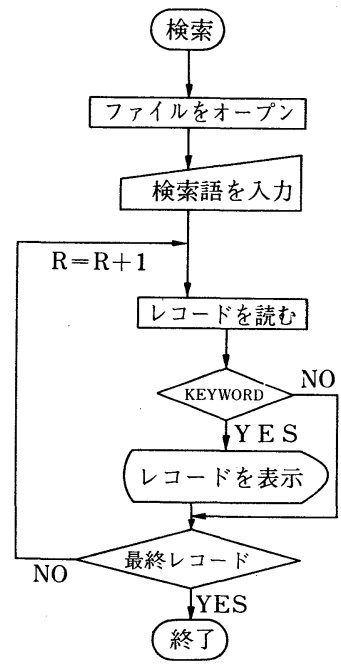

日獣会誌 $38 \quad 675 \sim 677 \quad$ (1985) 